Asian Journal of Managerial Science

ISSN: 2249-6300 Vol. 9 No.1, 2020, pp. 48-51

(C) The Research Publication, www.trp.org.in

\title{
Leadership Styles and its Implication on Employees
}

\author{
Kshitij Kasi Viswanath \\ $2^{\text {nd }}$ Year Student, B.B.A. LL.B (Hons.), Kirit P Mehta School of Law, NMIMS (Deemed to be University), Mumbai, India \\ E-mail: kshitijkasi513@gmail.com
}

\begin{abstract}
Leadership is an essential element in encouraging and guiding employees which helps in boosting their morale and eventually the effectiveness of the organization. This project aims at understanding the meaning of leadership along with the different styles of leadership that exist and its application in different scenarios. It also analyses the role of situational leadership in the larger bracket of leadership and how it is essential for the leader to change his outlook and method as and when the situation changes in the workplace. The research paper also talks about how aspects of a good manager influence his position in an organization and the correlation between stress and the style of leadership used.

Keywords: Leadership Styles, Employees
\end{abstract}

\section{INTRODUCTION}

In every managerial scenario, there is always a superior and a subordinate. It is the responsibility of the superior to ensure that the subordinate is well equipped with all the required knowledge and motivation. He/she must also ensure that his requirements are well communicated to the subordinate in order to ensure that the subordinate effectively completes the task assigned to him/her without any ambiguity.

From the above, we can understand that a good manager is also a good leader. A good leader is defined as one who inspires and encourages his/her subordinates to do a task efficiently, where he additionally communicates efficiently and also providing required autonomy and freedom to his employees to ensure they are happy and get work done with maximum output.

If we consider managers as individuals, everyone is unique and are endowed with different skills. For example, a manager may believe that every subordinate is an equal and thus may provide full autonomy to do his work, while another manager may not have the same faith on his subordinates, thus giving rise to newer and more unique managerial styles. This diversity, if used wisely, can favour the organization.

Leadership is one of the essentials of management, but bad leadership styles can lead to lack of productivity, distrust and dissatisfaction among the team members due to the dissent towards the leader. Thus, we can say that leadership has the ability to make or break the organization, making it important to understand the elements of leadership.

\section{STATEMENT OF PROBLEM}

The project aims to understand the different styles of management and the effects of the different elements of management on the employees such as stress, performance and approachability.

\section{CONCEPTUAL FRAMEWORK}

"Leadership is defined as a process of influencing others to accomplish the mission, inspiring their commitment, and improving the organisation." (Tom Peters)

According the author, leadership in this instance can be said to be the ability of a person to empathize, communicate and effectively delegate work to his/her subjects keeping in mind their abilities and weaknesses.

\section{NEED FOR STUDY}

The author believes that leadership styles in the field of management must be studied along with the different complexities of today's business environment in order to understand the importance of leadership in key roles in contemporary management.

In this scenario, there has been a great demand for good leadership. The diversity of the leadership traits that prevail among managers must be well understood to benefit the organization by putting the right person to the right job.

Moreover, there is a dire need to understand the link between the styles of leadership and the immediate and long-term effects it has on the working of the employees.

\section{OBJECTIVES OF THE STUDY}

This study aims to:

1. Understand the different styles of management

2. Assess the different elements of leadership to performance

3. To study the impact of approachability and transparency in a leader

4. Derive the link between stress and the styles of leadership 


\section{REVIEW OF LITERATURE}

Stogdill (1973) said in his works that there were as many definitions to leadership as the number of those who have tried to define it. Which means that every leader has his/her own meaning and cause to perform that job or task well(Bass \& Stogdill, 1990).

Kurt Lewin (1939) discovered that there were different styles of leadership that prevailed in society. In his system there were mainly three types of leadership styles. One is autocratic leadership, which spoke about how leaders, to a great extent, impose themselves on employees in a way that they want their methods, goals and image to progress in a direction that they would want. He also, in his theory, cleared the misconception that authoritarian management did not only mean yelling, screaming and screeching, but it actually meant that the leader kept a close tab on the subject, not giving the freedom he/she yearns for(Lewin et al., 1939).

Kurt Lewin further added the Laissez-Faire style of management, where the leader gave complete autonomy to his subjects in order to complete the tasks that he/she wanted to do. Over here, in contrary to the authoritarian style, the manager gave his subordinates full autonomy to do all the work they had to do, in a style and method of their choice.

The last style propounded by Kurt Lewin was the participative, democratic or mixed system of leadership. This system can somewhat be considered a mix of both authoritative and laissez faire as the manager provides autonomy to his subordinates, however, intervenes whenever necessary in order to check on the work that takes place in the organization. This by far is the most effective method that can be used.

Hersyand Blanchard (1979) propounded the situation of Situational leadership. Situational leadership basically meant that depending on the situation faced by the individual, he/she jumps to lead the crowd in the right direction(Hersey et al., 1979). Further, situational leadership can also be extended to the different scenarios that the leader faces and the different styles of leadership he can adopt viz. Authoritative, Democratic or Laissez Faire.

Snyder and Graves (1994) explained visionary leadership as that the ability of a manager to create a credible and realistic image of the company in the future, so as to make it attractive for the ones who are under him(Snyder \& Graves, 1994).

The principle of visionary leadership was further argued by Nanus (1992) where he says that this style of leadership is so energizing that it jump-starts future events by automatically arranging the required resources for the same (Nanus, 1992).
Avolio and Bass propounded the theory of Transactional Leadership, where he elicited the fact that leadership is a concept of transactional transfer of information (Avolio et al., 1999).

Burns (1978) propounded the idea of transformational leadership, where he spoke about the character of the leader such as charisma, intellect and considerate nature played a huge role in raising their esteem among their subjects (Kuhnert \& Lewis, 1987).

Robbins (1999) defined leadership as the ability to influence a group towards achieving goals, where the source of this influence is formal so that it is provided by the organizational structure of the company. He also stated that managers in an organization can gain the position of leaders merely by the virtue of their position, however not all managers can be leaders nor can all the leaders me managers i.e. leadership needn't necessarily be a fixed role, however, it can vary from person to person, depending on the situation in which he's placed. In Robbins' study, it was also found that the ability to be a leader and influence subordinates develops informally, outside the prescribed formal structure, as it is here that the true essence of the individual is portrayed(Robbins \& Judge, 2003).

Meccoby (1958) noted that a good leader was defined by a) the virtue of his position in the organization and $b$ ) by his ability to influence people to move in his direction. He observed in his works that a democratic leader had an upper hand over an authoritative leader, further observing that a democratic style of management not only increases the satisfaction of the employees, but also increases their productivity over the long run(Maccoby, 1958).

Svärd(2017) gave an insight about the importance of approachability and transparency in a leader, where she argues that with the presence of these elements in a leader, the subordinates look forward to working with them for the reason that they hold the same responsibility as the subordinate and they also receive feedback in an effective manner(Svärd, 2017).

Sinha and Singh (1961) in their study discovered that employee turnover and employee absenteeism was higher in organizations where employees felt dissatisfied with their job due to related reasons. The study also showed that when higher needs such as autonomy and freedom were provided, employee productivity increased. This basically correlates productivity and job satisfaction(Singh \& Sinha, 2013).

Farh et. al. (1990) found that extra-role behaviour in an organization i.e. greater autonomy positively affected the definition of the characteristics of their job. He further realized that this job satisfaction occurs because employees gain a sense of significance and status in an organization and makes them feel responsible doing their job. In other words, it can be said that the sense of freedom in employees gives them a clear view of their responsibilities and allows 
them to develop relationships of interdependency with other employees in order to better weave the work of the organization(Farh et al., 1990).

Pareek (2003) spoke about role stress where he emphasized that it was the feeling of stress and indecisiveness that a person felt during playing a role at a time. This brings out the human character of an employee, where he/she as a person plays multiple roles in life and being subject to numerous roles, he/she faces a feeling of confusion and pressure to fit in all those roles well (Sinha \& Subramanian, 2012).

Kahn (1964) spoke about role overload, where he emphasized on the concept that at times the work load i.e. the expectation from the role played in the job is so high that it becomes impossible to cope with the strain and pressure, causing the person to fail at the task that he or she is pursuing. This could also be a cause of over-delegation of work, or not feeling a sense of belongingness in the organization (Bolino\&Turnley, 2005).

The above research brings out the idea of what leadership is, how the different styles of leadership were propounded, what exactly is expected out of a leader, what situational leadership is and what exactly is the role of stress in an organization.

\section{RESEARCH GAP}

Considering all the information presented in the facts above, we can observe that there are certain discrepancies where we must intervene to bridge them. Firstly, who in an organization can be a leader. Then we can also assess when a leader must step in and take necessary action and in what style. Considering the date, we also need to understand the exact effect of good leadership qualities on the subordinates and evaluate the exact levels of stress that can prove detrimental to those who are subordinates.

\section{RESEARCH METHODOLOGY}

This research paper deals with an analysis of different theories in order to understand the links in the research gap.

\section{DISCUSSION}

After analysing all the facts and studies given above, we can infer leadership plays an integral part in defining the workspace in an organization. Leadership more than a tool of management is link between the people and their job and a source of charisma and motivation for those who work under. The style of management not only depends on the character of the manager, but also the type of work and the complexity of work. For example, a task such as a military operation requires huge amount of motivation, while a satellite launch by ISRO would require technical leadership, with high use of techniques and practical knowledge. It is essential to know that leadership is essential in every organization as it not only provides the employees motivation, but it also ensures the team places its effort in the right place in order to complete the task and align its goals to that of the larger organizational goal.

A good manager is one who can gather the individual efforts of all his subordinates, clear any misconceptions and animosities, and provide a clear route for work, thus ensuring affectivity and efficiency. However, it must be noted that the style of leadership that is applied in any situation has the ability to either make or break the organization; if the wrong style is used, it may lead to detrimental consequences as it may not be effective.

It is also important to note that every individual in an organization can be a leader in a given situation and it is also important to know that not every manager is a leader and not every leader is a manager. The positive aspects of a leader can be closely correlated to the performance of his/her team as they look up to the leader who through his/her approachability ensures a sense of confidence and good notions are maintained.

Lastly, the relationship between stress and the style of leadership plays an important role in assessing whether he/she is a good leader and whether the style adopted was a right one or not. As higher the stress, the lesser the productivity of the individual/ unit.

\section{CONCLUSION AND RESULTS}

Considering the facts and studies above, we can understand that the objectives as mentioned are answered in the following manner:

1. We can understand that every individual manager has his/her own way of showing leadership as it varies from person to person, rather than being uniform in nature.

2. There exists an autocratic method, laissez-faire method and democratic method, which gives rise to a large pool of possibilities with factors of each varying in a manager.

3. Through our studies above, we observed that elements such as autocracy and micromanagement in a leader leads to dissatisfaction and contempt among subordinates, leading to a fall in efficiency among them

4. At the same time, elements such as trust, freedom and general autonomy gives rise to a sense of satisfaction among the employees and greater appeal to towards their leader, thus creating greater satisfaction.

5. It was also seen that positive aspects of leadership such as approachability and accountability played a great role in creating a positive image of the leader among his subjects and helped the leader better lead his people and extract work from them in an effective and efficient manner.

6. It was also observed that employee turnover and absenteeism was in a way linked to the style of 
leadership so used where there was autocracy, the rates of job dissatisfaction were higher.

7. In the study above, we observed that stress also plays a huge role in determining the acts of both the leader and subordinate. Inefficient leadership skills lead to overburden among employees and a situation of stress on roles that are played by these people in different situation, thus hampering their personal lives as well, apart from their professional one. Thus, we can conclude by saying leadership is a continuous process which goes beyond its formal role and extends into the informal, both in a metaphysical state.

\section{REFERENCES}

[1] Bass, B. M., \& Stogdill, R. M. (1990). Bass \& Stogdill's handbook of leadership: research and managerial applications. Simon and Schuster.

[2] Bolino, M. C., \& Turnley, W. H. (2005). The personal costs of citizenship behavior: The relationship between individual initiative and role overload, job stress, and work-family conflict. Journal of Applied Psychology, 90(4), 740.

[3] Farh, J.-L., Podsakoff, P. M., \& Organ, D. W. (1990). Accounting for organizational citizenship behavior: Leader fairness and task scope versus satisfaction. Journal of Management, 16(4), 705-721.
[4] Hersey, P., Blanchard, K. H., \& Natemeyer, W. E. (1979). Situational leadership, perception, and the impact of power. Group \& Organization Studies, 4(4), 418-428.

[5] Kuhnert, K. W., \& Lewis, P. (1987). Transactional and transformational leadership: A constructive/developmental analysis. Academy of Management Review, 12(4), 648-657.

[6] Lewin, K., Lippitt, R., \& White, R. K. (1939). Patterns of aggressive behavior in experimentally created "social climates." The Journal of Social Psychology, 10(2), 269-299.

[7] Maccoby, H. (1958). The differential political activity of participants in a voluntary association. American Sociological Review, 23(5), 524-532.

[8] Nanus, B. (1992). Visionary Leadership: Creating a Compelling Sense of Direction for Your Organization. ERIC.

[9] Robbins, S. P., \& Judge, T. (2003). Essentials of organizational behavior (Vol. 7). Prentice Hall Upper Saddle River, NJ.

[10] Singh, M. P., \& Sinha, J. (2013). Job satisfaction in organizational executives. International Journal of Scientific and Research Publications, 3(4), 1-6.

[11] Snyder, N. H., \& Graves, M. (1994). Leadership and vision. Business Horizons, 37(1), 1-7.

[12] Svärd, P. (2017). 7-Accountability, transparency, and the role of information management. Enterprise Content Management, Records Management and Information Culture Amidst eGovernment Development, 83-96. 